\title{
Alternative food sources for the ladybird Brumoides foudrasii (Mulsant) (Coleoptera: Coccinellidae)
}

\author{
M. S. de Lima ${ }^{a}$, J. W. S. Melo ${ }^{b *}$ and R. Barros ${ }^{a}$ \\ aÁrea Fitossanidade, Departamento de Agronomia, Universidade Federal Rural de Pernambuco - UFRPE, \\ Rua Dom Manoel de Medeiros, s/n, Dois Irmãos, CEP 52171-900, Recife, PE, Brazil \\ bDepartamento de Fitotecnia, Universidade Federal do Ceará - UFC, Campus do Pici, Avenida Mister Hull, \\ Bloco 805, CEP 60356-000, Fortaleza, CE, Brazil \\ *e-mail: wagnermelo@ufc.br
}

Received: March 5, 2016 - Accepted: December 13, 2016 - Distributed: May 31, 2018

(With 1 figure)

\begin{abstract}
The predator Brumoides foudrasii (Mulsant) (Coleoptera, Coccinellidae) has been naturally found in plants infested by mealybugs. In this study, the striped mealybug Ferrisia dasylirii (Cockerell) (Hemiptera, Pseudococcidae) and Anagasta kuehniella Zeller (Lepidoptera, Pyralidae) eggs were evaluated as diets for the development and reproduction of B. foudrasii. Brumoides foudrasii immatures developed faster when fed with A. kuehniella eggs than when fed with $F$. dasylirii. However, the survival and longevity of $B$. foudrasii adults were not affected by the diets. Oviposition was more frequent when $B$. foudrasii females were fed with $F$. dasylirii (95\%) than those fed with A. kuehniella eggs (65\%). Brumoides foudrasii females fed with $F$. dasylirii were 2.5 times more fecund than those fed with A. kuehniella eggs. Although both diets may be considered proper for B. foudrasii, A. kuehniella eggs were more suitable for immature development, while $F$. darsyrili provided more nutritious resources for adult biological parameters as oviposition period, egg viability and fecundity. These results suggests that this predator can play an important role in regulating populations of the stripped mealybug $F$. dasylirii in the field.
\end{abstract}

Keywords: coccinellids, biological control, essential food, diet, laboratorial rearing.

\section{Fontes de alimento alternativo para a joaninha Brumoides foudrasii (Mulsant) (Coleoptera: Coccinellidae)}

\section{Resumo}

O predador Brumoides foudrasii (Mulsant) (Coleoptera, Coccinellidae) tem sido encontrado naturalmente sobre plantas infestadas por cochonilhas. Neste estudo, a cochonilha listrada Ferrisia dasyliri (Cockerell) (Hemiptera, Pseudococcidae) e ovos de Anagasta kuehniella Zeller (Lepidoptera, Pyralidae) foram avaliados como dietas para o desenvolvimento e reprodução de $B$. foudrasii. Formas amaturos de $B$. foudrasii desenvolveram-se mais rapidamente quando alimentados com ovos de A. kuehniella do que quando alimentados com $F$. dasyliri. No entanto, a sobrevivência e longevidade de adultos de $B$. foudrasii não foram afetadas pelas dietas. A oviposição foi mais freqüente em $B$. foudrasii alimentadas com F. dasylirii (95\%) do que aqueles alimentados com ovos de A. kuehniella (65\%). Fêmeas de B. foudrasii alimentadas com $F$. dasylirii foram 2,5 vezes mais fecundas do que aquelas alimentados com ovos de $A$. kuehniella. Embora ambas as dietas possam ser consideradas apropriadas para $B$. foudrasii, ovos de $A$. kuehniella foram mais adequadas para o desenvolvimento de imaturos, enquanto $F$. dasylirii proporcionou mais recursos nutritivos para os parâmetros biológicos do adulto, tais como período de oviposição, viabilidade de ovos e fecundidade. Estes resultados sugerem que este predador pode ser potencialmente eficiente na regulação populacional da cochonilha $F$. dasylirii em campo.

Palavras-chave: coccinelídeos, controle biológico, alimento essencial, dieta, criação de laboratório.

\section{Introduction}

The genus Brumoides (Coleoptera, Coccinellidae, Chilocorini) consists of about ten recognized species. Brumoides, like other Chilocorini genera, features a wide range of prey including aphids, whiteflies, psyllids, mealybugs, and mites (Chapin, 1965). They are predominantly found in the old world (Kovár, 1995); however, four species have been reported in the New World: Brumoides blumi (Nunenmacher), Brumoides histrio (Fall), and Brumoides 
septentrionis (Weise) are found in North America (Gordon, 1985) while Brumoides foudrasii (Mulsant) is found in South America (Giorgi et al., 2014).

The first observations of $B$. foudrasii in Brazil indicate an association of this predator with some species of mealybugs such as Dactylopius opuntiae (Cockerell) (Hemiptera, Dactylopiidae) in forage cactus (Lima et al., 2011) and Ferrisia dasylirii (Cockerell) (Hemiptera: Pseudococcidae) in cotton (Giorgi et al., 2014). Recent studies suggest that the latter species can pose a threat to cotton crops in the semiarid region of Brazil (Oliveira et al., 2013).

Giorgi et al. (2014) report $F$. dasylirii predation by B. foudrasii. However in the fields, Brumoides species can behave as opportunistic predators feeding on a wide range of prey (Arif et al., 2012), suggesting that this behavior may not clearly indicate the suitability of prey (Evans et al., 1999). According to Dixon (2000), prey used by coccinellids depend on the abundance of prey available in the environment where they live. Since coccinellids feed on a wide range of prey, it is difficult to determine for some species a correct relationship between predator and prey (Hodek, 1973). This behavior is often seen as an emergency strategy when the preferred food is scarce (Castro-Guedes et al., 2016). The amount and quality of prey is very important because influences directly on the biological aspects of Coccinellidae (Dixon, 2000). Various parameters, including developmental time, survival, and female fecundity, have been used to determine the suitability of prey in coccinellids (Matos and Obrycki, 2006). Hagen (1987) and Hodek and Honěk (1996) report that some prey consumed in the field may not be nutritionally appropriate for the development and reproduction of coccinellids. When the ingested food is few or of poor quality, the development time usually increases and the oviposition, fecundity and fertility decrease. Prey species used by Coccinelidae are commonly classified as essential or alternatives (Hodek and Honek, 1996). Food that provides complete development and reproduction of coccinellids is considered essential while that which serves only as an energy source and is able to prolong survival is characterized as alternative (Hodek, 1996).

Coccinellids have been the group of predators most often associated with biological control (Hodek and Honěk, 1996; Jervis and Kidd, 1996). According to Dixon (2000), coccidophagous coccinellids have been the most effective as biological control agents, especially in classical biological control programs. Studies with Brumoides species suggest that these coccinellids have potential as biological control agents for mealybug species (Wheeler, 2003; Han et al., 2007; Arif et al., 2012; Chakraborty and Korat, 2013).

The natural occurrence of $B$. foudrasii on cotton plants infested with $F$. dasylirii, as well as its predatory behavior on this species in the field, suggests that this coccinellid can act as a natural enemy of mealybugs (Giorgi et al., 2014). However, evidence to support this hypothesis requires the confirmation that $B$. foudrasii can use $F$. dasylirii as the only source of food that allows its development and reproduction.
Lepidopteran eggs, particularly those of the Mediterranean flour moth Anagasta kuehniella (Lepidoptera, Pyralidae) have been extensively used as factitious food for rearing Coccinellidae in place of natural prey (Kato et al., 1999; Santos et al., 2009; Silva et al., 2013; Zazycki et al., 2015; Castro-Guedes et al., 2016). Moreover, A. kuehniella eggs can be produced easily and at low cost, making this prey propitious for rearing Coccinellidae (Specty et al., 2003; De Clercq et al., 2005; Silva et al., 2009). This study evaluated and compared the food suitability of $F$. dasylirii and Anagasta kuehniella eggs to B. foudrasii, which may help to implement rearing methods of this species.

\section{Material and Methods}

The study was conducted at the Insect Biology and Insect Plant Resistance Laboratory (LBIRPI) at the Universidade Federal Rural de Pernambuco (UFRPE). Insect rearing techniques were adapted from Sanches et al. (2002). Stocks of the mealybug $F$. dasylirii in LBIRPI were used to prepare test cultures of mealybug; test cultures of the predator B. foudrasii were generated from insects collected on cotton crops in the municipality of Surubim in Pernambuco State. Insect rearing and experiments were carried out in a room with the following controlled conditions: $25 \pm 1{ }^{\circ} \mathrm{C}$, $70 \pm 10 \% \mathrm{RH}$, and 12 hours photoperiod.

Pumpkins of the jacarezinho variety [Cucurbita moschata (Duch). Duch. ex Poir.] were acquired from the local food supply center (CEASA) in Recife at the early stage of maturation. Pumpkins were washed, dried at room temperature, and placed in plastic trays $(30 \times 45 \times 4 \mathrm{~cm})$ lined with paper towel. Actively reproductive mealybug females were released in the stalk region of non-infected pumpkins.

The period from infestation to complete pumpkin colonization with adult mealybugs is approximately 30 days. Subsequent infestations were performed by overlapping non-infested pumpkins on infested pumpkins allowing the passage of nymphs and adults; this condition was maintained for two days. Infested pumpkins were used to feed B. foudrasii in mass-rearing conditions.

Brumoides foudrasii adults collected in the field were transferred to the laboratory and confined in plastic cages of $50 \times 30 \times 25 \mathrm{~cm}$ (length $\times$ width $\times$ height) containing rectangular openings $(35 \times 20 \mathrm{~cm})$ on the sides, which were sealed with voile to allow air circulation. Pumpkins infested with the mealybug $F$. dasylirii at different stages of development were placed inside the boxes to feed the coccinellids. Water was offered through moistened cotton balls inside $80 \mathrm{~mL}$ plastic containers. Infested pumpkins were continuously provided to maintain food abundance.

Plastic Petri dishes ( $5.5 \mathrm{~cm}$ diameter) lined with filter paper to serve as a substrate for oviposition were used to house adult predator couples. Couples were approximately $48 \mathrm{~h}$ old. Twenty couples were housed in twenty Petri dishes which were sealed with plastic film. Ferrisia dasylirii nymphs and adult females were provided in abundance to feed these couples. The filter paper and entire petri 
dish were surveyed once a day in a stereomicroscope to count the number of laid eggs. After hatching, a total of 100 larvae were manually transferred to individual Petri dishes lined with filter paper where $F$. dasylirii nymphs were offered as feed.

Larvae instar change was monitored daily in a stereomicroscope by observing exuviae left after molting. Prey from the previous day was replaced daily with fresh and abundant prey. Brumoides foudrasii larvae were fed with $F$. dasylirii neonate nymphs up until the second instar. After that, they received mealybug adult females as food up until the pre-pupal stage, which was characterized by cessation of movement. The daily observations of immature stages enabled the determination of the duration and viability of these stages.

The experiment of B. foudrasii individuals fed with A. kuehniella eggs was carried out according to the methodology described above. Petri dishes were lined with filter paper, and A. kuehniella eggs were provided in abundance daily. Immature forms were monitored as described before to determine the development and viability from immature stages to adulthood.

Newly emerged B. foudrasii adults were sexed using morphological characteristics. Males have six visible sternites while females have only five (Corrêa and Almeida, 2010). Couples were formed and individually placed in Petri dishes $(5.5 \mathrm{~cm}$ diameter) sealed with plastic film. These couples were divided into two groups of 20 each; one was fed with $F$. dasylirii while the other was fed with A. kuehniella eggs, with both foods were provided in abundance. These dishes were lined with filter paper as the substrate for oviposition.

The filter paper and entire petri dish were surveyed once a day in a stereomicroscope to count the number of laid eggs. These eggs were separated into Petri dishes and identified to evaluate the duration and viability of this phase. The following parameters were determined through these daily observations: pre-oviposition, oviposition, and post-oviposition period, the number of eggs/female, egg viability, and female longevity. These parameters were compared between the groups fed with $F$. dasylirii and A. kuehniella eggs.

The T-test [Proc TEST, Method: pooled (for equality of variances)] (SAS, 2002) was used to analyze the effect of each diet on the developmental time of each B. foudrasii immature stage. Viability in the immature period was evaluated by survival curves estimated using the Kaplan-Meier method and compared using the Log-Rank test (Proc LIFETEST) (SAS, 2002). The diet effect on the biological parameters evaluated in B. foudrasii females (longevity, pre-oviposition, oviposition, and post-oviposition period, the number of eggs/female, and egg viability) were analyzed by the T-test [Proc TEST, Method: pooled (for equality of variances)] (SAS, 2002).

\section{Results}

\subsection{Development of $B$. foudrasii immature}

The development of $B$. foudrasii from the larval to adult stage was faster when they were fed with A. kuehniella eggs compared to those fed with $F$. dasylirii nymphs and adults $\left(\mathrm{T}_{152}=-17.72 ; \mathrm{P}<0.0001\right)$ (Table 1$)$. With the exception of the third larval instar that did not differ between diets $\left(\mathrm{T}_{152}=-0.99 ; \mathrm{P}=00: 32\right)$, all the other immature stages showed longer duration when fed with F. dasylirii $\left(\mathrm{T}_{152}>3.43 ; \mathrm{P}<0.0008\right)$ (Table 1$)$.

Diet did not influence the survival of $B$. foudrasii immature stages (larvae to adults) $\left(\chi^{2}=0.65 ; \mathrm{P}=0.4175\right)$, which corresponded to $85 \%$ in the group fed with A. kuehniella eggs and $81 \%$ in the group fed with $F$. dasylirii (Figure 1); the mortality of immatures was concentrated in the first two larval instars (up to the $10^{\text {th }}$ day after hatching) in both groups.

\subsection{Longevity and reproduction of B. foudrasii adults}

Brumoides foudrasii females showed similar longevity regardless of diet $\left(\mathrm{t}_{38}=-1.47 ; \mathrm{P}=0.15\right)$ (Table 2). The pre-oviposition period was longer in the group fed with A. kuehniella eggs compared to that fed with F. dasylirii, while oviposition and post-oviposition periods were longer in the group fed with $F$. dasylirii compared to that fed with A. kuehniella eggs $\left(\mathrm{t}_{30}>6: 33 ; \mathrm{P}<0.0001\right)$ (Table 2).

It is worth noting that 7 out of the $20 \mathrm{~B}$. foudrasii females fed with $A$. kuehniellai eggs did not lay eggs ( $65 \%$ of females) compared to only 1 out of 20 females fed with $F$. dasylirii ( $95 \%$ of females). The first eggs were laid after 16 days of feeding when females were fed with A. kuehniella eggs and after 4.5 days of feeding when females were fed with $F$. dasylirii. The number of eggs per females was approximately 2.5 times higher when the predator was fed with $F$. dasylirii than in the group fed with A. kuehniella eggs $\left(\mathrm{t}_{30}=-2.29 ; \mathrm{P}=0.029\right)$ (Table 2).

Table 1. Developmental periods (days) of B. foudrasii when reared on different diets.

\begin{tabular}{lccc}
\hline & Prey & A. kuehniella eggs $(\mathbf{n}=\mathbf{7 3})$ & $\boldsymbol{F}$. dasylirii $(\mathbf{n}=\mathbf{8 1})$ \\
\hline & $1^{\text {st }}$ Instar & $4.1 \pm 0.08 \mathrm{~B}$ & $5.5 \pm 0.17 \mathrm{~A}$ \\
Larva & $2^{\text {nd }}$ Instar & $4.3 \pm 0.07 \mathrm{~B}$ & $5.3 \pm 0.14 \mathrm{~A}$ \\
& $3^{\text {rd }}$ Instar & $4.2 \pm 0.09 \mathrm{~A}$ & $4.0 \pm 0.10 \mathrm{~A}$ \\
& $4^{\text {th }}$ Instar & $5.1 \pm 0.09 \mathrm{~B}$ & $5.9 \pm 0.12 \mathrm{~A}$ \\
& $1^{\text {st }}-4^{\text {th }}$ Instar & $18.0 \pm 1.40 \mathrm{~A}$ & $20.5 \pm 0.40 \mathrm{~A}$ \\
\hline Pupa & & $7.9 \pm 0.17 \mathrm{~B}$ & $11.1 \pm 0.152 \mathrm{~A}$ \\
\hline Immature stages & & $32.3 \pm 0.26 \mathrm{~B}$ & $37.5 \pm 0.15 \mathrm{~A}$ \\
\hline
\end{tabular}

Averages followed by same letters in the rows do not differ significantly $(t$-test; $p>0.05)$. 
In addition, $B$. foudrasii fed with $F$. dasylirii provided higher egg viability $\left(\mathrm{t}_{30}=-5.78 ; \mathrm{P}<0.0001\right)$ and shorter embryo development time $\left(\mathrm{T}_{152}=3.43 ; \mathrm{P}=0.0008\right)$ compared with the group fed with $A$. kuehniella eggs. The sex ratio was 0.52 in individuals fed with $F$. dasylirii and 0.46 in individuals fed with A. kuehniella eggs (Table 2).

\section{Discussion}

Both tested prey (A. kuehniella eggs or F. dasylirii) enabled the development and reproduction of $B$. foudrasii. According to the results obtained in this study, A. kuehniella eggs and $F$. dasylirii are considered essential prey to their predator $B$. foudrasii, following the classification of Hodek and Honek 1996. Similar results were obtained by Lima et al. (2016), using Zagreus bimaculosus Mulsant (Coleoptera: Coccinellidae) as predator.

Although considered essential prey, A. kuehniella eggs and $F$. dasylirii mealybugs influenced $B$. foudrasii immatures and adults differently. Brumoides foudrasii

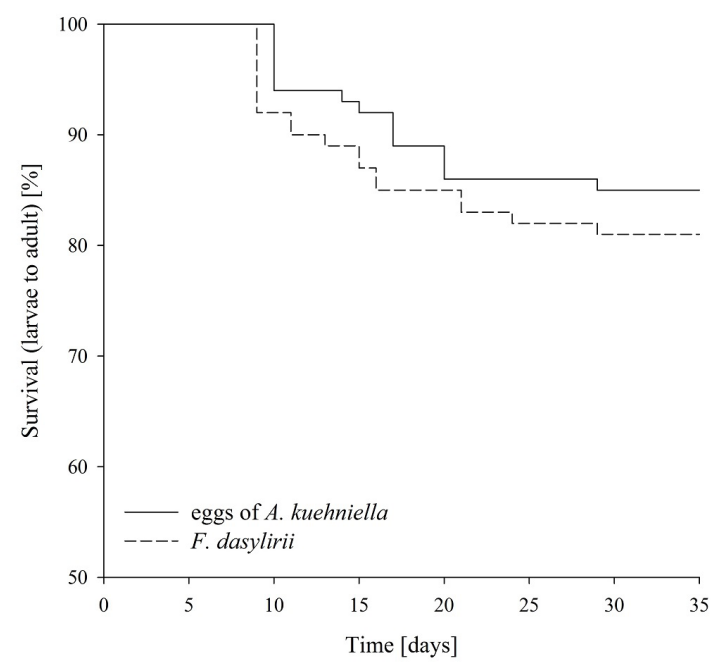

Figure 1. The survival rate of $B$. foudrasii immature stages reared on different diets. Survivorship curves are not significantly different by the Log-Rank test. immature forms fed with A. kuehniella eggs developed faster than those fed with $F$. dasylirii, however, the diet did not affect the viability of immature forms of $B$. foudrasii. According to Panizzi and Parra (2009), differences in the developmental time of predators may be associated with nutritional differences between preys. Thus, our results suggest that there are nutritional differences between F. dasylirii and A. kuehniella eggs, being the latter nutritionally more advantageous to the development of B. foudrasii. In addition, several studies have indicated that the initial instars of coccinellids have difficulty feeding on active prey (Majerus, 1994; Phoofolo and Obrycki, 1995; Dixon, 2000; Jalali et al., 2009). This may explain the longer duration of the 1 st and 2 nd instars of $B$. foudrasii fed with $F$. dasylirii nymphs (crawlers). It is worth noting that when in contact with new prey, some predators, especially those with pre-oral digestion such as coccinellids, need some time to adapt to their predation behavior (handling the prey) and ingest its content (Cohen, 1998; Grenier and De Clercq, 2003). Thus, despite the fact that the predator $B$. foudrasii was fed with $F$. dasylirii for a few generations, its performance might improve through the passing of generations.

The viability of immature stages seems to be associated with water content in the food. According to Michaud and Grant (2005), the amount of available water in the food can affect the survival of ladybird larvae. Since it is difficult evaluate water content in both prey (eggs and mealybug nymphs) they were offered ad libitum, hence, it is possible that predators did not did not experience water limitation, which would explain the observed similarity in viability rates.

Brumoides foudrasii females showed similar longevity regardless of diet. However, only $65 \%$ of females fed with A. kuehniella eggs initiated reproduction by laying eggs after 16 days of feeding. A total of $95 \%$ of females fed with F. dasylirii laid eggs; the first eggs were laid after 4.5 days of feeding. According to Seagraves (2009), coccinellids need to consume a certain amount of nutrients above the level needed for maintenance, in order to start reproduction.

Table 2. Reproductive parameters of B. foudrasii when reared on different diets.

\begin{tabular}{lccc}
\hline & Prey & A. kuehniella & F. dasylirii \\
\hline $\mathrm{N}^{1}$ & & 20 & 20 \\
\hline Longevity & $\mathrm{n}^{*}$ & $67.2 \pm 4.98 \mathrm{~A}$ & $77.4 \pm 3.71 \mathrm{~A}$ \\
\hline & Pre-oviposition & 13 & 19 \\
& Oviposition & $16.1 \pm 2.32 \mathrm{~A}$ & $4.5 \pm 0.44 \mathrm{~B}$ \\
Fertility & Post-oviposition & $31.4 \pm 3.23 \mathrm{~B}$ & $45.6 \pm 0.64 \mathrm{~A}$ \\
& Eggs/female & $19.7 \pm 4.12 \mathrm{~B}$ & $27.3 \pm 0.22 \mathrm{~A}$ \\
& Viability of eggs & $26.5 \pm 8.07 \mathrm{~B}$ & $68.0 \pm 15.26 \mathrm{~A}$ \\
& Duration of the egg stage & $46.6 \pm 3.88 \mathrm{~B}$ & $83.1 \pm 4.28 \mathrm{~A}$ \\
& Sex ratio & $6.3 \pm 0.10 \mathrm{~A}$ & $5.9 \pm 0.06 \mathrm{~B}$
\end{tabular}

Averages followed by same letters in the rows do not differ significantly $(t$-test; $p>0.05) ;{ }^{1}$ Number of repetitions; $*$ Number of females that had started oviposition. 
Our results show that $F$. dasylirii or A. kuehniella eggs were nutritionally adequate for the reproduction of B. foudrasii. However, B. foudrasii females fed with $F$. dasylirii were about 2.5 times more fecund than those fed with A. kuehniella eggs. Although both diets allowed $B$. foudrasii reproduction, differences in the nutritional content of each prey may explain the higher oviposition rate of females fed with $F$. dasylirii compared to those fed with $A$. kuehniella eggs. Egg viability of B. foudrasii was greater when fed with $F$. dasylirii (83.1\%) than when fed with A. kuehniella eggs (46.6\%). In natural conditions, B. foudrasii can feed on other prey such as other species of mealybugs and aphids, which can maximize the fitness and performance of adults in the field.

Our study provides evidence of divergent nutritional requirements between larvae and adults of $B$. foudrasii. Although A. kuehniella eggs were more suitable for immature development, while $F$. darsyrili provided more nutritious resources for adult biological parameters, as oviposition period, egg viability and fecundity (Table 1 and 2). These results are in agree with Michaud (2005), who has reported that prey suitability may differ for larval and adult coccinellids. Still according to him, adult coccinellids have stronger mandibles and more highly developed digestive systems than do larvae and likely process some types of food more efficiently. Moreover, larvae utilize resources for growth and development, whereas adults use them for dispersal and reproduction, and the nutritional demands of these various functions may differ.

The results obtained in this study show that $F$. dasylirii enabled the development and reproduction of B. foudrasii, and thus this mealybug may be included as an essential food for B. foudrasii. This suggest that the predator may play a potentially important role regulating mealybug's populations in agroecosystems. Moreover, our study demonstrates the possibility of $B$. foudrasii mass rearing fed with $A$. kuehniella eggs and the use of this alternative prey as a diet for $B$. foudrasii can help reducing the cost of mass production, which represents a major limitation in biological control programs.

\section{References}

ARIF, M.I., RAFIQ, M.S.W., MEHMOOD, N. WAZIR, S. and GHAFFAR, A., 2012 [viewed 04 March 2016]. Studies on cotton mealybug, Phenacoccus solenopsis (Pseudococcidae: Homoptera), and its natural enemies in Punjab, Pakistan. International Journal of Agriculture and Biology [online], vol. 14, pp. 557-562. Available from: http://agris.fao.org/aos/records/PK2013000188

CASTRO-GUEDES, C.F., ALMEIDA, L.M., PENTEADO, S.R.C. and MOURA, M.O., 2016. Effect of different diets on biology, reproductive variables and life and fertility tables of Harmonia axyridis (Pallas) (Coleoptera, Coccinellidae). Revista Brasileira de Entomologia, vol. 60, no. 3, pp. 260-266. http:// dx.doi.org/10.1016/j.rbe.2016.03.003.

CHAKRABORTY, D. and KORAT, D.M., 2013. Biology and Feeding Efficiency of Brumoides suturalis (Fabricius) on Phenacoccus solenopsis Tinsley. Journal of Biological Control., vol. 27, pp. 39-42. http://dx.doi.org/10.18641/jbc\%2F27\%2F1\%2F45496.

CHAPIN, E.A., 1965. The genera of the Chilocorini (Coleoptera, Coccinellidae). Bulletin of the Museum of Comparative Zoology, vol. 133, pp. 227-271.

COHEN, A.C., 1998. Solid-to-liquid feeding: the insect(s) story of extra-oral digestion in predaceous arthropoda. American Entomologist., vol. 44, no. 2, pp. 103-116. http://dx.doi.org/10.1093/ ae/44.2.103.

CORREAA, G.H. and ALMEIDA, L.M., 2010. Revision of the genus Harpasus Mulsant (Coleoptera, Coccinellidae, Chilocorini). Revista Brasileira de Entomologia, vol. 54, no. 3, pp. 350-360. http://dx.doi.org/10.1590/S0085-56262010000300002.

DE CLERCQ, P., BONTE, M., VANSPEYBROECK, K., BOLCKMANS, K. and DEFORCE, K., 2005. Development and reproduction of Adalia bipunctata (Coleoptera Coccinellidae) on eggs of Ephestia kuehniella (Lepidoptera: Phycitidae) and pollen. Pest Management Science, vol. 61, no. 11, pp. 1129-1132. PMid:16144016. http://dx.doi.org/10.1002/ps.1111.

DIXON, A.F.G., 2000. Insect predator-prey dynamics: ladybirds Beetles \& biological control. London: Cambridge University Press. 257 p.

EVANS, E.W., STEVENSON, A.T. and RICHARDS, D.R., 1999. Essential versus alternative foods of insect predators: benefits of a mixed diet. Oecologia, vol. 121, no. 1, pp. 107-112. PMid:28307878. http://dx.doi.org/10.1007/s004420050911.

GIORGI, J.A., LIMA, M.S. and VANDENBERG, N.J., 2014. The first record of Brumoides foudrasii (Mulsant) (Coleoptera: Coccinellidae: Chilocorini) from South America, with notes on its Biology. Coleopterists Bulletin, vol. 68, pp. 336-338. http:// dx.doi.org/10.1649/0010-065X-68.2.336.

GORDON, R.D., 1985. The Coccinellidae (Coleoptera) of America north of Mexico. Journal of the New York Entomological Society, vol. 93, no. 1, pp. 1-912.

GRENIER, S. and DE CLERCQ, P., 2003. Comparison of artificially vs. naturally reared natural enemies and their potential for use in biological control. In: J.C. VAN LENTEREN, ed. Quality control and production of biological control agents: theory and testing procedures. Wallingford: CABI Publishing, p. 115-131.

HAGEN, K.S., 1987. Nutritional ecology of terrestrial insect predators. In: F. SLANSKY JUNIOR and J.G. RODRIQUEZ, eds. Nutritional ecology of insects, mites, spiders, and related invertebrates. New York: John Wiley \& Sons. pp. 533-577.

HAN, S.H., NDIAYE, A.B. and HEMPTINNE, J.L., 2007. Host-plants and predators of Rastrococcus invadens Williams, 1986, newly introduced in Dakar area, Senegal (Hemiptera, Pseudococcidae). Bulletin de la Société Entomologique de France, vol. 112, pp. 121-125.

HODEK, I. and HONĚK, A., 1996. Ecology of Coccinellidae. Dordrecht: Kluwer Academic Publishers.

HODEK, I., 1973. Biology of Coccinellidae. Prague: Academia the Hague.

HODEK, I., 1996. Food relationships. In: I. HODEK and A. Honěk, eds. Ecology of Coccinellidae. Dordrecht: Kluwer Academic, pp. 143-238.

JALALI, M.A., TIRRY, L. and DE CLERCQ, P., 2009. Effects of food and temperature on development, fecundity and life-table parameters of Adalia bipunctata (Coleoptera: Coccinellidae). 
Journal of Applied Entomology, vol. 133, no. 8, pp. 615-625. http://dx.doi.org/10.1111/j.1439-0418.2009.01408.x.

JERVIS, M. and KIDD, N., 1996. Insect natural enemies: practical approaches to their study and evaluation. New York: Chapman \& Hall, 491 p.

KATO, C.M., BUENO, V.H.P., MORAES, J.C. and AUAD, A.M., 1999. Criação de Hippodamia convergens Guérin-Meneville (Coleoptera:Coccinellidae) em ovos de Anagasta kuehniella (Zeller) (Lepidoptera: Pyralidae). Anais da Sociedade Entomológica do Brasil, vol. 28, no. 3, pp. 455-459. http://dx.doi.org/10.1590/ S0301-80591999000300010.

KOVÁŘ, I., 1995. Revision of the genera Brumus Muls. and Exochomus Redtb. (Coleoptera, Coccinellidae) of the Palaearctic region. Part I. Acta Entomologica Musei Nationalis Pragae, vol. 44, pp. 5-124.

LIMA, M.S., MELO, J.W.S. and BARROS, R., 2016. Biology of Zagreus bimaculosus Mulsant (Coleoptera: Coccinellidae), a predator of Ferrisia dasylirii (Cockerell) (Hemiptera: Pseudococcidae). Coleopterists Bulletin, vol. 70, no. 2, pp. 314-320. http://dx.doi. org/10.1649/0010-065X-70.2.314.

LIMA, M.S., SILVA, D.M.P., HIRAM, M.F., WELLINGTON, M.F., LEONARDO, D.S. and PARANHOS, B.A.J., 2011. Predadores associados á Dactilopius opuntiae (Hemiptera: Dactylopiidae) em palma forrageira no Estado de Pernambuco, Brasil. Revista Chilena de Entomologia, vol. 36, pp. 51-54.

MAJERUS, M.E.N., 1994. Ladybirds. London: Harper Collins.

MATOS, B. and OBRYCKI, J.J., 2006. Prey suitability of Galerucella calmariensis L. (Coleoptera: Chrysomelidae) and Myzus lythri (Schrank) (Homoptera: Aphididae) for development of three predatory species. Environmental Entomology, vol. 35, no. 2, pp. 345-350. http://dx.doi.org/10.1603/0046-225X-35.2.345.

MICHAUD, J.P. and GRANT, A.K., 2005. Suitability of pollen sources for the development and reproduction of Coleomegilla maculata (Coleoptera: Coccinellidae) under simulated drought conditions. Biological Control, vol. 32, no. 3, pp. 363-370. http:// dx.doi.org/10.1016/j.biocontrol.2004.11.001.

MICHAUD, J.P., 2005. On the assessment of prey suitability in aphidophagous Coccinellidae. European Journal of Entomology, vol. 102, no. 3, pp. 385-390. http://dx.doi.org/10.14411/eje.2005.055.

OLIVEIRA, M.D., BARBOSA, P.R.R., SILVA-TORRES, C.S.A. and TORRES, J.B., 2013. Performance of the striped mealybug Ferrisia virgata Cockerell (Hemiptera: Pseudococcidae) under variable conditions of temperature and mating. Neotropical Entomology, vol. 43, no. 1, pp. 1-8. PMid:27193398. http:// dx.doi.org/10.1007/s13744-013-0171-z.

PANIZZI, A.R. and PARRA, J.R.P., 2009. Bioecologia e nutrição de insetos: base para o manejo integrado de pragas. Brasília: Embrapa Informação Tecnológica, 1164 p.
PHOOFOLO, M.W. and OBRYCKI, J.J., 1995. Comparative life history studies of Nearctic and Palearctic populations of Coccinella septempunctata (Coleoptera Coccinellidae). Environmental Entomology, vol. 24, no. 3, pp. 581-587. http:// dx.doi.org/10.1093/ee/24.3.581.

SANCHES, N.F., CARVALHO, R.S., SILVA, E.S., SANTOS, I.P. and CALDAS, R.C., 2002. Técnica de criação do predador exótico Cryptolaemus montrouzieri Mulsant (Coleoptera; Coccinellidae) em laboratório. Cruz das Almas: Embrapa Mandioca e Fruticultura. 8 p. Circular Técnica, no. 47.

SANTOS, N.R.P., SANTOS-CIVIDANES, T.M., CIVIDANES, F.J., ANJOS, A.C.R. and OLIVEIRA, L.V.L., 2009. Aspectos biológicos de Harmonia axyridis alimentada com duas espécies de presas e predação intraguilda com Eriopis connexa. Pesquisa Agropecuária Brasileira, vol. 44, no. 6, pp. 554-560. http://dx.doi. org/10.1590/S0100-204X2009000600002.

SAS INSTITUTE - SAS, 2002. SAS/STAT user's guide: version 8.02 - TS level 2MO. Cary: SAS Institute Inc.

SEAGRAVES, M.P., 2009. Lady beetle oviposition behavior in response to the trophic environment. Biological Control, vol. 51, no. 2, pp. 313-322. http://dx.doi.org/10.1016/j.biocontrol.2009.05.015.

SILVA, R.B., CRUZ, I., FIGUEIREDO, M.L.C., TAVARES, W.S., SERRÃO, J.E. and ZANUNCIO, J.C., 2013. Development and reproduction of Olla v-nigrum (Coleoptera: Coccinellidae) fed Anagasta kuehniella (Lepidoptera: Pyralidae) eggs supplemented with an artificial diet. The Florida Entomologist, vol. 96, no. 3, pp. 850-858. http://dx.doi.org/10.1653/024.096.0319.

SILVA, R.B., ZANUNCIO, J.C., SERRÃO, J.E., LIMA, E.R., FIGUEIREDO, M.L.C. and CRUZ, I., 2009. Suitability of different artificial diets for development and survival of stages of the predaceous ladybeetle Eriopis connexa. Phytoparasitica, vol. 37, no. 2, pp. 115-123. http://dx.doi.org/10.1007/s12600-008-0015-2.

SPECTY, O., FEBVAY, G., GRENIER, S., DELOBEL, B., PIOTTE, C., PAGEAUX, J.F., FERRAN, A. and GUILLAUD, J., 2003. Nutritional plasticity of the predatory ladybeetle Harmonia axyridis (Coleoptera Coccinellidae): comparison between natural and substitution prey. Archives of Insect Biochemistry and Physiology, vol. 52, no. 2, pp. 81-91. PMid:12529863. http:// dx.doi.org/10.1002/arch.10070.

WHEELER, A.G., 2003. Brumoides septentrionis Davisi (Leng) (Coleoptera: Coccinellidae): distribution, host-plant associations, and habitats of a seldom-collected lady beetle. Proceedings of the Entomological Society of Washington, vol. 105, pp. 50-58.

ZAZYCKI, L.C.F., SEMEDO, R.E.S., SILVA, A., BISOGNIN, A.Z., BERNARDI, O., GARCIA, M.S. and NAVA, D.E., 2015. Biology and fertility life table of Eriopis connexa, Harmonia axyridis and Olla v-nigrum (Coleoptera: Coccinellidae). Brazilian Journal of Biology, vol. 75, pp. 969-973. https://dx.doi.org/10.1590/15196984.038144.096.0319. 